\title{
Influence of Business Characteristics on Selection of Investment Evaluation Techniques: The Case of Tanzanian SMEs
}

\author{
Rose J. Katabi (MBA, Finance and Banking) \\ PhD Student, School of Business, Mzumbe University \\ P.O.Box 6, Mzumbe-Tanzania \\ E-mail: rosejkatabi@gmail.com \\ Romanus L. Dimoso (PhD). Economics) \\ Senior Lecturer in Economics \\ Mzumbe-Tanzania \\ E-mail: rdimoso@mzumbe.ac.tz
}

Received: August 26, 2018

doi:10.5296/jmr.v10i4.13634
Accepted: Sep. 28, 2018

Published: October 1, 2018

URL: https://doi.org/10.5296/jmr.v10i4.13634

\begin{abstract}
This study was conducted in two phases; first as a survey and second as a case study. The study used a cross-sectional survey design to explain the business characteristics influencing the selection of investment evaluation techniques among Tanzanian SMEs. Purposive sampling technique was used to collect data to a sample of 301 SMEs drawn from SIDO in Dar es Salaam and Dodoma regions. Data were collected though questionnaires and transformed into suitable format for analysis using statistical packages for the survey, while for the case study interviews were used. Statistical techniques used in this study were descriptive (frequency distributions) and inferential statistics (multivariate analysis) which were used to determine whether or not there is a relationship between business characteristics and selection of investment evaluation techniques. Results of this study shows that, sales growth, industry of business, level of education and finance education of owners, were the business characteristics that influence the selection of investment evaluation techniques.

Theoretical and practical contributions in the area of investment decisions for SMEs in Tanzania are made based on the findings of the study. On theoretical contributions, the study
\end{abstract}




\section{Macrothink

provided a better understanding on small business characteristics and how they influenced the selection of investment evaluation techniques. On practical contributions, owners should maintain high sales growth; improve education background by attending short courses on financial management, because these two characteristics significantly affect the selection of investment evaluation techniques.

Keywords: Business Characteristics, Investment Evaluation Techniques, SMEs, Selection, Tanzania 


\section{Introduction}

Investment decisions are among the most important decisions to be made by the business. There are several reasons which make investment decisions to be critical decisions as highlighted by Pandey (1976), Srivastava and Misra (2008). According to them, they influence the firm's growth in the long run, they affect the risk of the firm, they involve commitment of large amount of funds, they are irreversible, or reversible at substantial loss, they are among the difficult decisions to make. Hence, businesses need to make sure that they are making the right decision on deciding about what investments to undertake. One of the tools which can assist owners or decision makers of SMEs to evaluate and select investment projects is the investment evaluation techniques. These techniques are grouped into two; discounted cash flow methods and non- discounted cash flow methods (Pandey, 1976). These techniques have advantages and disadvantages which SMEs are supposed to be aware of.

Earlier studies on the investment decisions theory and practice have indicated the existence of a gap between the theory and practice (Mukherjee \& Henderson, 1987; Mvula, 1988; Kaijage, 1992; Graham \& Harvey, 2001; John, 2007; Awomewe \& Ogundele, 2008; Kipesha, 2009; Brijlal \& Quesada, 2009; and Olawale et al, 2010). However, these studies have concentrated much on the wide use or non-use of the investment evaluation techniques. It should be understood that there are many factors which may influence the selection and adoption of a certain investment evaluation technique. By knowing these factors, it may assist SMEs to make better investment decisions on selecting the right investment evaluation techniques. This study therefore, investigates the influence of business characteristics on the selection of investment evaluation techniques for SMEs in Tanzania.

\section{Literature review}

\subsection{Characteristics of the business}

Several researchers have highlighted different business characteristics and their influence on investment decisions practices for large as well as small businesses (Graham \& Harvey, 2001; Anand (2002); Brounen et al.,2004; Fernando, 2005; Danielson \& Scott, 2006; Leon et al.,2008; Truong et al., 2008; Brijlal \& Quesada, 2009; Pal \& Verma, 2011; Daunfeldt \& Hartwig, 2012; Hartwig, 2012; Pratheepkanth et al.,2013; Ahmed, 2013; Yasmin, 2015; Swarnapali, 2015).

Size of the business was found to be the most important characteristic which affects the selection or use of investment evaluation techniques. The size of the business in different studies has been expressed in terms of the number of employees, sales revenue, value of assets, and turnover of the business. Studies conducted by Graham and Harvey (2001), Anand (2002), Brounen et al. (2004), Danielson \& Scott (2006), Brijlal and Quesada (2009), Daunfeldt and Hartwig (2012), Hartwig (2012), Pratheepkanth et al. (2013), and Ahmed (2013) observed that the size of the business influence the choice of investment evaluation techniques. However, there are few studies which contrary to the observation of the above studies observed that size does not affect the choice of investment evaluation techniques (Fernando, 2005; Truong et al., 2008; Leon et al., 2008; Swarnapali, 2015, and Yasmin, 
2015).

Sector of business is another factor that influences the selection of investment evaluation techniques. Danielson and Scott (2006) noted that gut feel was used extensively by businesses in the service sector. Hartwig (2012) observed that sector of business had an effect on the choice of investment evaluation techniques. Brijlal and Quesada (2008) found that payback period to be the most method used in manufacturing businesses while NPV to be used in service and retail businesses. According to Leon, et al (2008), businesses in different sectors may behave differently in terms of capital budgeting practices. It is further argued that this may be due to differences in technology, competition, human resource skills, amount of investment in fixed assets, business risk, and so forth. However, in their study it was found that there is no difference between industries and the use of investment evaluation technique.

Another factor considered is the growth of the company. The Growth of the business can be explained in terms of sales growth, price - earnings ratio, or growth in revenues. Anand (2002), Danielson and Scott (2006), Daunfeldt and Hartwig (2012), and Ahmed (2013) concluded that the growth of the company has impact on the choice of investment evaluation techniques. Contrary to the above conclusion, Graham and Harvey (2001), Pal and Verma (2011), and Swarnapali (2015) noted that the growth of the business has no impact on the choice of the investment evaluation technique.

Form of ownership was found to have impact on the selection of investment evaluation techniques (Hartiwig, 2012). Opposing to this conclusion, Brounen et al. (2004), Danielson and Scott (2006), Leon et al. (2008), Swarnapali (2015) found that there is no impact of form of ownership on the choice of investment evaluation techniques.

Another factor considered is the age of the business. Studies conducted by Danielson and Scott (2006), and Leon et al. (2008) concluded that age of the business is related to the choice of investment evaluation techniques. Specifically, Leon et al (2008) assumed that the period of listing of the business in the stock exchange would be positively related to usage the of DCF techniques. The assumption for testing the influence of the period of listing on the extent of use of DCF techniques was due to the fact that the listed businesses are subject to greater regulations and market monitoring. The businesses which have been listed over a long period of time would have been subject to greater scrutiny than those recently listed. On the other hand, Danielson and Scott (2006) observed that businesses less than six years use DCF methods. They further argued that although younger firms are less likely to have complete management team in place, it is also possible that banks may encourage newer firms to demonstrate adequate planning (and project evaluation) procedures before qualifying for credit.

Owner education level is another important factor that influences the selection of investment evaluation techniques. Graham and Harvey (2001) and Brounen et al. (2004) observed that CEOs with MBAs are more likely than non - MBA CEOs to use NPV. However, Daunfeldt and Hartwig (2012) found that educated CEOs used both IRR and discounted payback period more frequently. Surprisingly, Hartwig, (2012) noted that CEO education did not lead to a more frequent use of sophisticated methods. Furthermore, Leon et al. (2008) found that 
university education respondents use DCF techniques as opposed to those without a university education. Ahmed (2013) revealed that CFOs with high level of education (PhD, MBA, Professional Certificate) tend to use more NPV and ARR. Interestingly, Danielson and Scott (2006) observed that owners with graduate school level education use payback period and combined methods. On the other hand, Brijlal and Quesada (2009) observed that decision -makers that did not receive formal education mainly used their intuition or gut feel as compared to those that received formal training that were inclined to use DCF methods. This observation concurred with the observation of Danielson and Scott (2006) that those owners without college degree resort to gut feel more frequently. It was also revealed that the use of DCF was more to owners that received formal finance and accounting training.

Age of owners was also an important factor that was considered to affect the selection of investment evaluation techniques as highlighted in the previous studies conducted by Graham and Harvey (2001), Danielson and Scott (2006), Daunfeldt and Hartwig (2012), Hartwig (2012), Pratheepkanth et al. (2013), Ahmed (2013), and Yasmin (2015). Graham and Harvey (2001) observed that mature CEOs use payback period significantly more often than younger CEOs. Daunfeldt and Hartwig (2012) found that older CEOs used ARR more often, while Yasmin (2015) found that companies with older CEOs have a tendency to rely more on non - DCF methods.

\subsection{Investment evaluation techniques}

There are various techniques which can be used to evaluate investments as indicated in the finance literature. The methods are grouped into two: discounted cash flow methods and nondiscounted cash flow methods (Pandey, 1979). The discounted cash flow methods which have been discussed in the theoretical literature review, discount the net future cash flows using a discounted rate in order to get the present value of cash flows. These methods consider the time value of money. Under this category, four methods have been identified: the net present value (NPV), the internal rate of return (IRR), profitability index (PI), and the modified internal rate of return (MIRR). Under the second category of non-discounted cash flow methods, three methods have been identified; the payback period, discounted payback period, and accounting rate of return (ARR). These methods do not consider time value of money.

There are studies on investment evaluation techniques which show that different businesses use different methods to evaluate investments. There are differences on the methods used from study to study and from one business to another. However, generally, it has been revealed in most cases the methods used are quite different from the requirements of the theory that business are to use DCF techniques when evaluating investments. Studies conducted by Graham and Harvey (2001), Danielson and Scott (2006), Brijlal and Quesada (2009) observed high usage of payback period among the small businesses; while the usage of ARR was documented in the studies by Vos and Vos (2000) and John (2007). There are other studies which found that businesses do not use the theoretically known methods but rather they use gut feel or intuition. Studies conducted by Vos and Vos (2000), Hammer (2003), Danielson and Scott (2006), and Kipesha (2009) provide evidence on the use of gut feel or intuition. Several reasons were pointed out as to why there is a continual use of 
non-discounted cash flow methods in evaluating investments. The first reason is that liquidity concerns and cash flow challenges explain why small businesses do not use DCF methods (Danielson and Scott, 2006). Second, managers of small firms are not well trained (Runyon. 1983). This argument suggested that managers would use the more sophisticated techniques if they understand them better. This argument concurred with the observation made by Uddin and Chowdhury (2009) that, NPV is the ultimately suggested method of investment that involves estimation of cash flows and discount rate. These two tasks need expertise and relevant knowledge, or may find it cost ineffective to hire such kind of expertise. In small business, owners or decision makers may lack this knowledge. Third, is the cost of analysing projects. According to Runyon (1983), the costs of analysing these projects are fixed, so it may not be economical to incur them when the project itself is relatively small.

Another noteworthy observation from the above studies is the variation of the samples used for studies whereby and the methods for data collection. Other studies used very small samples whereas others used large samples. Other studies used questionnaires, or interviews, or both to collect data. These differences might results in the inconsistencies of the findings.

The literature review has revealed the importance of investment decisions, and that investments are to be evaluated using laid down criteria. However, the selection of investment evaluation techniques can be influenced by the characteristics of the business such as; industry of business, sales growth, age of business, number of employees, age of owners, and level of education of owners. The purpose of this study therefore, is to test how business characteristics influence the selection of investment evaluation techniques. The hypothesis to test the relationship between the business characteristics and selection of investment evaluation techniques can be stated as follows:-

$\mathrm{H}_{2}$ : characteristics of businesses positively influence the selection of investment evaluation techniques used by SMEs.

\section{Methodology}

This study was conducted in Tanzania specifically in Dar es Salaam and Dodoma regions to analyse the factors which influence the selection of investment evaluation techniques among Tanzanian SMEs. The study was conducted in two stages; first, a written survey was carried out secondly, as a case study.

\subsection{Sample and data collection}

In order to test the relationship between business characteristics and selection of investment evaluation techniques as indicated in the stated hypothesis, a questionnaire and personal interviews were employed to get the required data. A sample 301 SMEs from Dodoma and Dar es Salaam regions was obtained through a non-probability sampling method which is known as purposive sampling. A defined criterion was set to get the sample: first, the SME should employ 5 to 99 people or having capital investment from 5 to 800 million shillings. Second, the sector of business should be manufacturing, service or distribution. Third, the contact person should be limited to the owner, manager, or finance manager. 


\subsection{Data analysis}

Analysis of data was done in two phases namely; descriptive and inferential. In the descriptive analysis, tables and frequency distribution were used to describe the features of the research aggregate. The multinomial logit model was used to measure the association between business characteristics and selection of investment evaluation techniques. The model was appropriate because the responses were unordered such as a set of investment evaluation method has more than two outcomes (Hair, 2006). On the other hand, inferential analysis was done for making inferences and conclusions from the findings of the study. The categorized, tabulated data and evidence from the study were combined to address the research problem and then interpretation was done to analyse the data.

\subsection{Study variables and measurement}

In this study, the independent variable is business characteristics. The literature review indicated that, there are characteristics of the business which can influence the selection of investment evaluation techniques. The characteristics are: industry/ sector of business, sales growth, business age, employment, age of owners, and education background of owners. Table 1 shows how this variable was measured. Investment evaluation technique is considered to be the dependent variable. The investment evaluation techniques included; discounted cash flow methods (NPV, IRR, PI, and MIRR), Non- discounted cash flow methods (payback period, and accounting rate of return), and gut feel/ intuition.

Table 1. Measurement of business characteristics

\begin{tabular}{|c|c|c|c|}
\hline Variable & Dimension & Indicators/Measurement & Variable type \\
\hline \multirow{6}{*}{$\begin{array}{l}\text { Small } \\
\text { business } \\
\text { characteris } \\
\text { tics }\end{array}$} & Type of industry & $\begin{array}{l}\text { Type of industry in three categories: manufacturing, } \\
\text { distribution, or service. (Danielson and Scott, 2006; Brijlal } \\
\text { and Quesada, 2008; Ross, 2015). }\end{array}$ & Nominal \\
\hline & Sales growth & $\begin{array}{l}\text { Whether the business has attained a sales growth of } 20 \% \text { or } \\
\text { higher, } 10-19 \% \text {, or less than } 10 \% \text { (Danielson and Scott, } \\
\text { 2006; Ahmed, 2013). }\end{array}$ & Ordinal \\
\hline & Age of business & $\begin{array}{l}\text { Number of years in business according to categories; } 1-5 \\
\text { years, 6-10 years, } 11-20 \text { years, more than } 20 \text { years } \\
\text { ( Danielson and Scott, 2006). }\end{array}$ & Ordinal \\
\hline & $\begin{array}{l}\text { Number } \\
\text { of employees }\end{array}$ & $\begin{array}{l}\text { Number of employees in categories: } 5,5-15,16-30,31-49 \\
\text { employees (Vos and Vos, 2000; Danielson and Scott, 2006; } \\
\text { Brijlal and Quesada, 2008). }\end{array}$ & Ordinal \\
\hline & $\begin{array}{l}\text { Formal and finance } \\
\text { education }\end{array}$ & $\begin{array}{l}\text { The highest level of education attained by the respondent in } \\
\text { categories: less than a degree, degree, postgraduate studies, } \\
\text { and professional studies. (Danielson and Scott, 2006; Brijlal } \\
\text { and Quesada, 2008). }\end{array}$ & Nominal \\
\hline & Age of owner & $\begin{array}{l}\text { Age of owners in years according to categories }<35 \text { years, } \\
35-44 \text { years, } 45-54 \text { years, } 55 \text { years and above (Danielson and } \\
\text { Scott, 2006). }\end{array}$ & Ordinal \\
\hline
\end{tabular}


Source: Literature Review

\subsection{Case study}

In order to understand more on the business characteristics influencing the selection of investment evaluation techniques, case study strategy was used apart from the survey strategy. According to Yin (2003), the case study research can be exploratory, descriptive, or explanatory. This study adopted explanatory case study because it intended to examine closely in order to explain the business characteristics influencing the selection of investment evaluation techniques in the SMEs of Tanzania. The study was conducted in Dar es Salaam involving four purposively selects SMEs.

\section{Empirical results}

\subsection{Description of the sample}

A sample of 301 SMEs was used for the survey and 4 SMEs for case study. In this study in terms of SMEs characteristics, it is indicated that most small businesses are in manufacturing activities (44.5\%), and are sole proprietors $(60.5 \%)$, and reports a higher sales growth $(48.2 \%)$ in the past two years. the age of these businesses range from one to five years $(45.8 \%)$, and number of employees from one to five employees $(64.5 \%)$. At the same time, in terms of characteristics of owners, it is indicated that most SMEs are dominated by female $(51.8 \%)$, and most respondents are owners of the business (75.1\%). As far as formal and finance education is concerned, most SMEs owners do not have degrees (39.9\%). These SMEs most of them are run by owners who are less than 54 years of age $(84.6 \%)$.

\subsection{Investment evaluation techniques}

The investment evaluation techniques which were used to assess the financial viability of a major investment in the business for the purpose of this study are presented in Table 2.

Table 2. Investment Evaluation Techniques

\begin{tabular}{lcr}
\hline Investment evaluation technique & Number of observations & Percent \\
\hline Payback period & 86 & 28.6 \\
Accounting Rate of Return & 83 & 27.6 \\
Gut feel or Intuition & 96 & 31.8 \\
Combination & 2 & 0.7 \\
No method & 34 & 11.3 \\
Total & $\mathbf{3 0 1}$ & $\mathbf{1 0 0}$ \\
\hline
\end{tabular}

Source: Field data

Results in Table 2 above indicate that the first used method is gut feel 96 (31.8\%), and second used method is the payback period $86(28.6 \%)$. this is followed by Accounting Rate of Return $83(27.6 \%)$, and $2(0.7 \%)$ used combined methods. $34(11.3 \%)$ did not indicate the methods used to evaluate investments. 


\subsection{Hypothesis testing}

Multinomial Logistic Regression was used to analyse the business characteristics, influencing the selection of an investment evaluation technique made by SMEs. The model contained seven independent variables (age of owners, highest level of education, finance education, sales growth, industry of business, number of employees in the business and age of the business). The following was the hypotheses to be tested using the multinomial logistic regression:-

$\mathrm{H}_{4}$ : Characteristics of businesses positively affect the choice of investment evaluation techniques used by SMEs.

The following multinomial logit model is estimated using maximum likelihood function:

$$
\begin{gathered}
\mathrm{p}_{i j}=\frac{\exp \left(X_{i} \beta_{j}\right)}{\sum_{k=1}^{J} \exp \left(X_{i} \beta_{k}\right)} \\
\mathrm{p}_{i j}=\frac{1}{\sum_{k=1}^{J} \exp \left[X_{i}\left(\beta_{k}-\beta_{i}\right)\right]}
\end{gathered}
$$

Where;

$\mathrm{J}=$ alternatives to choose (i.e. evaluation methods)

$\mathrm{p}_{i j}=$ probability that a business $i$ chooses evaluation method $j$

$X_{i}=$ the characteristics of the business e.g. age of business

$\beta=$ parameter vectors

This model can be estimated by the likelihood function

$$
\log \mathrm{L}=\sum_{i} \sum_{\mathrm{j}} \mathrm{y}_{\mathrm{ij}} \mathrm{p}_{\mathrm{ij}}
$$

Where $\mathrm{y}_{\mathrm{ij}}$ is equal to 1 if a business chooses alternative $j$ and $\mathrm{y}_{\mathrm{ij}}$ equal to 0 otherwise.

\subsection{Results from the Mutlinomial logistic regression}

The full model containing all predictors was statistically significant $\chi^{2}(38)=82.03, p<$ 0.0001 , indicating that the model was able to explain how respondents chose the investment 
evaluation techniques. The model as a whole explained the pseudo $-R^{2}$ metric $14.02 \%$. This metric shows variance in the choice of investment evaluation techniques. From the findings of this study, it is shown that the intercept of the model had -2Log likelihood of 292.63 and a model with all variables has a -2Log likelihood of 251.61. This shows an improvement of the model from the intercept model.

The multicollinearity in the multinomial logistic regression is detected by examining the standard errors of the $\mathbf{b}$ coefficients. A standard error larger than 2.0 indicates numerical problems such as multicollinearity among the independent variables, zero cells, and the like. In this analysis, two variables (Dedulev3, and Dfined3) had numerical problems having a standard error larger than 2.0, hence, they are not interpreted.

The relationship of individual independent variables and the dependent variable is shown in Table 3. In this analysis the reference category is gut feel.

Table 3. Results from multinomial logistic regression

\begin{tabular}{|c|c|c|c|c|c|c|c|}
\hline \multicolumn{8}{|c|}{ Iteration 0: $\quad \log$ likelihood $=-292.63094$} \\
\hline \multicolumn{4}{|c|}{ Multinomial logistic regression } & \multicolumn{2}{|c|}{ Number of obs } & $=$ & 267 \\
\hline & & & & \multicolumn{2}{|c|}{ LR chi2(38) } & $=$ & 82.03 \\
\hline & & & & \multicolumn{2}{|c|}{ Prob $>$ chi2 } & $=$ & 0.0000 \\
\hline Log likelihood $=-2$ & .61763 & & & \multicolumn{2}{|c|}{ Pseudo R2 } & $=$ & 0.1402 \\
\hline invtechs & Coef. & Err. & \multicolumn{2}{|c|}{$\mathrm{P}>|\mathrm{z}|$} & \multicolumn{2}{|c|}{ Interval] } & payback pe $\sim \mathrm{d}$ \\
\hline Dedulev1 | & -1.717792 & .9173458 & -1.87 & 0.061 & -3.515756 & & .0801733 \\
\hline Dedulev2 & -1.041084 & 1.280602 & -0.81 & 0.416 & -3.551017 & & 1.46885 \\
\hline Dedulev3 & -1.608555 & 2.190318 & -0.73 & 0.463 & -5.9015 & & 2.68439 \\
\hline Dfined1 $\mid$ & 2.774324 & .9330928 & 2.97 & 0.003 & .9454953 & & 4.603152 \\
\hline Dfined 2 & 2.729687 & 1.272682 & 2.14 & 0.032 & .2352758 & & 5.224098 \\
\hline Dfined3 | & 2.605402 & 2.196106 & 1.19 & 0.235 & -1.698887 & & 6.909691 \\
\hline Dindust1 $\mid$ & -.5835741 & .6438574 & -0.91 & 0.365 & -1.845511 & & .6783632 \\
\hline Dindust 2 & -.2100154 & 6447453 & -0.33 & 0.745 & -1.473693 & & 1.053662 \\
\hline Dsgrowt1 | & -1.491202 & .5050859 & -2.95 & 0.003 & -2.481152 & & -.5012517 \\
\hline Dsgrowt 2 & -.7721087 & .481685 & -1.60 & 0.109 & -1.716194 & & .1719766 \\
\hline Destab1 | & .193735 & .387489 & 0.50 & 0.617 & -.5657294 & & .9531995 \\
\hline Destab2 | & .0130717 & .5796081 & 0.02 & 0.982 & -1.122939 & & 1.149083 \\
\hline Destab3 | & 1.065321 & .9725688 & 1.10 & 0.273 & -.840879 & & 2.971521 \\
\hline Demploy1 | & -.1350798 & .4116735 & -0.33 & 0.743 & -.9419452 & & .6717855 \\
\hline Demploy2 | & .1839098 & .7555891 & 0.24 & 0.808 & -1.297018 & & 1.664837 \\
\hline Demploy3 | & -34.61454 & $1.10 \mathrm{e}+08$ & -0.00 & 1.000 & $-2.15 e+08$ & & $2.15 \mathrm{e}+08$ \\
\hline Dagegp1 | & .0078992 & .4285584 & 0.02 & 0.985 & -.8320598 & & .8478582 \\
\hline Dagegp2 | & .280593 & .4309313 & 0.65 & 0.515 & -.5640169 & & 1.125203 \\
\hline Dagegp3 | & -.7678727 & .8540163 & -0.90 & 0.369 & -2.441714 & & .9059685 \\
\hline _cons $\mid$ & 2373821 & .7732889 & 0.31 & 0.759 & -1.278236 & & 1.753001 \\
\hline
\end{tabular}




\begin{tabular}{|c|c|c|c|c|c|c|}
\hline \multicolumn{7}{|c|}{ accounting $\sim \mathrm{n} \mid$} \\
\hline Dedulev1 | & -.2711692 & .7973588 & -0.34 & 0.734 & -1.833964 & 1.291625 \\
\hline Dedulev2 | & 1.962233 & 1.405537 & 1.40 & 0.163 & -.7925685 & 4.717034 \\
\hline Dedulev3 | & .4027177 & 2.24162 & 0.18 & 0.857 & -3.990776 & 4.796212 \\
\hline Dfined1 | & .95493 & .8017059 & 1.19 & 0.234 & -.6163847 & 2.526245 \\
\hline Dfined2 | & -.6001622 & 1.393407 & -0.43 & 0.667 & -3.33119 & 2.130866 \\
\hline Dfined3 | & -.8032025 & 2.244021 & -0.36 & 0.720 & -5.201403 & 3.594998 \\
\hline Dindust1 | & -1.440053 & .5608149 & -2.57 & 0.010 & -2.53923 & -.3408763 \\
\hline Dindust2 | & -1.483866 & .5686393 & -2.61 & 0.009 & -2.598378 & -.3693532 \\
\hline Dsgrowt1 | & -.0773768 & .5602626 & -0.14 & 0.890 & -1.175471 & 1.020718 \\
\hline Dsgrowt2 | & .24243 & .5616951 & 0.43 & 0.666 & -.8584722 & 1.343332 \\
\hline Destab1 | & -.3730124 & .3918924 & -0.95 & 0.341 & -1.141107 & .3950826 \\
\hline Destab2 | & -.1941774 & .5702579 & -0.34 & 0.733 & -1.311862 & .9235075 \\
\hline Destab3 | & -36.10004 & $2.57 \mathrm{e}+07$ & -0.00 & 1.000 & $-5.05 e+07$ & $5.05 \mathrm{e}+07$ \\
\hline Demploy1 | & .2213486 & .4102861 & 0.54 & 0.590 & -.5827974 & 1.025495 \\
\hline Demploy2 | & .5147659 & .7893619 & 0.65 & 0.514 & -1.032355 & 2.061887 \\
\hline Demploy3 | & -36.47921 & $1.12 \mathrm{e}+08$ & -0.00 & 1.000 & $-2.19 \mathrm{e}+08$ & $2.19 \mathrm{e}+08$ \\
\hline Dagegp1 | & -.4222489 & .4344639 & -0.97 & 0.331 & -1.273783 & .4292847 \\
\hline Dagegp2| & .1038952 & .4257959 & 0.24 & 0.807 & -.7306494 & .9384397 \\
\hline Dagegp3 | & .5477144 & .7240868 & 0.76 & 0.449 & -.8714696 & 1.966898 \\
\hline cons $\mid$ & .760353 & .7311488 & 1.04 & 0.298 & -.6726724 & 2.193378 \\
\hline
\end{tabular}

(invtechs $==$ gutfeel or intuition is the base outcome)

Under Payback period relative to gut feel Table 3 shows that, only three of the independent variables made a unique contribution to the model (level of education, level of finance education, and sales growth). The strongest predictor for making choice of payback period as the investment evaluation techniques is the level of finance education (less than degree) with coefficient of 2.774324. This indicates that businesses owners whose level of education is less than degree were two times more likely to select payback period than businesses owners, whose level of finance education is professional studies, controlling for other factors in the model.

The least of the predictors was the sales growth (10\% to $19 \%)$ with coefficient of -1.491202 . This indicates that respondents whose sales growth is $10 \%$ to $19 \%$ were over 1 times less likely to select payback period than businesses whose sales growth is less than $10 \%$ controlling for other factors in the model. The interpretation of the variables which made unique contribution to the model is presented below.

The first variable which made unique contribution is the level of education. The results show that level of education (less than degree) is significant at $10 \%$ with coefficient of -1.717792 . This means that businesses owners with less than degrees decrease the likelihood of choosing payback period method compared to owners with professional qualifications controlling for other factors in the model. This means they will select gut feel when evaluating investments.

The second variable is the Level of finance education. The results show that level of finance 
education (less than degree) is significant at $1 \%$ with coefficient of 2.774.324. This means that businesses owners with finance education (less than degrees) increase the likelihood of choosing payback period method compared to owners with professional qualifications controlling for other factors in the model. At the same time, results show that level of education (degree) is significant at $5 \%$ with coefficient 2.729687 . This means that businesses owners with finance education (degrees) increase the likelihood of choosing payback period method compared to owners with professional qualifications controlling for other factors in the model.

Sales growth is the third variable which made unique contribution to the model. The results indicated that sales growth from $10 \%$ to $19 \%$ is significant at $1 \%$ with coefficient of -1.717792 . This means that businesses with sales growth from $10 \%$ to $19 \%$ decrease the likelihood of choosing payback period compared to businesses with sales growth less than $10 \%$ controlling for other factors in the model.

On the aspect of Accounting Rate of Return relative to gut feel as shown in Table 3, only one of the independent variables made a unique contribution to the model (industry of business).The strongest predictor for making the choice of investment evaluation techniques is manufacturing with the coefficient of -1.483866 . This indicates that businesses which are in the manufacturing industry were over 1 time less likely to select the ARR than those in other types of industry, controlling for all other factors in the model. The coefficient of for the industry of business (service) was -1.440053 indicating that businesses which are in the service industry are less likely to select the ARR method than those with other types of industry, controlling for other factors in the model. In other words businesses will choose the gut feel as the method for evaluating investments.

\section{Discussion of the findings}

The business characteristics influencing the selection of investment evaluation techniques were grouped into two: characteristics of the business which includes industry of the business, sales growth, establishment of business, and number of employees, and characteristics of business owners which include level of education, level of finance education, and age of owners.

\subsection{Characteristics of the business}

Variables which were included in the characteristics of the business were industry of business, sales growth, establishment of business, and number of employees. The findings show that the main activity of SMEs is in manufacturing, and that majority of SMEs reports higher sales growth. However, these SMEs are young in terms of age and small in terms of number of employees. On testing the simultaneous impact of the SMEs characteristics (sales growth, industry of business, number of employees, and establishment of business) on investment evaluation techniques; sales growth and industry of business were found to be significant factors influencing the selection of investment evaluation techniques. Considering sales growth, these results are consistent with the results reported by Anand (2002), Danielson and Scott (2006), Daunfeldt and Hartwig (2012), and Ahmed (2013).In these studies it was 
concluded that the growth of the business has impact on the choice of investment evaluation technique. The findings further shows that in relation to payback period method, the likelihood of choosing ARR and gut feel methods increases with sales growth of business. While estimating the multinomial logistic equation, we expected that businesses with greater sales growth when it is getting old, and the number of workers increase, it will have to expand or replace equipments. Hence, it may need to use the recommended methods and ARR. This is because on expansion or replacing of long term assets, the business may need to raise a new capital, either by obtaining a bank loan or by attracting new investors. In either case, the business' historical and projected financial statements will be used to communicate information about the firm investors (Danielson and Scott, 2006). In this study, descriptive statistics shows that most SMEs have a sales growth of $20 \%$ or greater and are $48.2 \%$ of the sample, followed by sales growth of $10 \%$ to $19 \%$ which are $35.5 \%$ of the sample. Hence, these results are consistent with what we expected on the use of ARR, but contrary to our expectations on the use of recommended methods such as DCF. On industry of business, results are consistent with that of Danielson and Scott (2006), Brijlal and Quesada (2008), and Hartwig and Daunfeldt (2012) who observed that there is a relationship between industry of business and the use of investment evaluation techniques. The findings further show in relation to gut feel, the likelihood of choosing ARR decreases with industry of business (service and manufacturing). This means that SMEs will select gut feel. While estimating the multinomial logistic equation, we expected that businesses in the manufacturing industry to use the recommended methods that is discounted cash flow methods while businesses in the service and distribution industry to use less sophisticated methods such as payback period. Hence, these results are contrary to our expectations.

\subsection{Characteristics business owners}

Variables which were included in the characteristics of the business were; position in the business, level of education, level of finance education, and age. The findings show that most respondent were owners of the business. As far as formal and finance education are concerned, most SMEs owners do not have degrees. These SMEs most of them are run by owners who are less than 54 years of age. On testing the simultaneous impact of owners characteristics on investment evaluation techniques; level of education, and finance education, of owners were found to be significant factors influencing the selection of investment evaluation techniques. These findings are consistent with the findings in the studies conducted by Graham and Harvey (2001), Danielson and Scott (2006), Leon et al. (2008), Brijlal and Quesada (2009), Daunfeldt and Hartwig (2012), and Ahmed (2013), and who found that level of education influence the choice of investment evaluation techniques. The findings further show that in relation to gut feel, the likelihood of choosing payback period methods decreases with level of education. However, the likelihood of choosing payback period method increases with the level of finance education. While estimating the multinomial logistic regression equation, we expected more educated people to use the recommended investment evaluation methods such as discounted cash flow methods; which they might be more familiar because that is what they have been taught. However, for owners whose level of education is less than a degree we expected them to use less sophisticated 
methods such as payback period, ARR, or gut feel. The descriptive statistics regarding education and age of owners, it was revealed that $39.9 \%$ of owners their level of education is less than a degree, hence it is not surprising to note that SMEs use non- recommended methods such as ARR although this is contrary to what we expected. Hence, our findings are contrary to what we expected on the use of investment evaluation techniques.

\subsection{Discussion of the findings from the case study}

On characteristics of owners, the most important thing to note is the level of education and finance education. Findings shows that four SMEs have reached form four. All of them do not have finance education. With such kind of level of education and with the absence of the finance education, it could mean that these owners may have difficulty in understanding and applying different types of investment evaluation techniques. Uddin and Chowdhury (2009) argued that the decision makers in small businesses may lack knowledge and expertise to use DCF techniques and hence use less sophisticated methods such as payback period. Brijlal and Quesada (2008) observed that the use of DCF was more used by those owners that received formal finance and accounting training.

With regard to the characteristics of the business, it was found that the type of industry for these SMEs is manufacturing. In addition to that three of them are in the distribution industry. The sales growth of the SMEs range from $10 \%$ to $20 \%$. The most important thing to note here is that manufacturing businesses are supposed to be large enough and hence use the recommended methods such as the discounted cash flow methods to evaluate investments. This is because of the large amount of capital involved. Another noteworthy observation is that sales growth of SMEs. Sales growth of the business will enable the SMEs to expand the business or replace long term assets (Danielson and Scott, 2006). Hence, SMEs are supposed to maintain high sales growth.

\section{Summary and conclusions}

Business characteristics were considered to be among the factors that influence the selection of investment evaluation techniques: hence one hypothesis was formulated. The hypothesized relationship was tested and was supported. As a result of testing the hypothesis, sales growth, industry of business, the level of education, and finance education were found to be significant factors to the selection of investment evaluation techniques. However, the numbers of employees, establishment of business, and the age of owners, were found not to be significant factors to the selection of investment evaluation techniques. Hence, from this study, it can be concluded that the characteristics of business are factors influencing the selection of investment evaluation techniques.

\section{Implications from the study}

The study also has theoretical and practical implications in terms of business characteristics. There are several factors which can affect how SMEs select the investment evaluation techniques for making investment decisions. In this study the factors which were considered were related to SMEs characteristics, and owners' characteristics. This study contributes to the existing knowledge by identifying the factors affecting the choice of investment 
evaluation techniques. With respect to SMEs characteristics, the study has shown how different characteristics significantly influenced the choice of investment evaluation techniques. Specifically, sales growth, and industry of business were identified as the business characteristics which affected the selection. The study has identified the owners' characteristics which influenced the selection. These characteristics are level of education and finance education. The findings of this study indicated that the choice of investment evaluation techniques which are used in investment decisions depends on several factors. If that is the case, then SMEs when making investment decisions are supposed to be aware of them. First, sales growth of the business should highly be considered. This is because high sales growth may assist the business to expand or modernize its long term assets. Therefore, businesses should maintain high sales growth. Second, the level of education of owners plays an important role in investment decisions. Therefore, SMEs owners with level of education below degree should strive to attend short courses related to financial management so that they may be trained on how to make investment decisions for success of their SMEs.

\section{References}

Ahmed, I.E. (2013). Factors determining the selection of capital budgeting techniques. Journal of Finance and Investment Analysis, 2(2), 77-88.

Anand, M. (2002). Corporate finance practices in India: A survey. Vikalpa, 27(4), 29-56. https://doi.org/10.1177/0256090920020404

Andor, G., Mohant, S.K., \& Toth, T. (2011). Capital budgeting practices: A survey of Central and Eastern European Firms. World Bank, 1, 1-45.

Awomewe, A \& O, Ogundele, (2008). The importance of the Payback method in Capital Budgeting Decision, MBA Thesis, Blekinge Institute of Technology.

Brijal, P., \& Quesada, L. (2009). The use of capital budgeting techniques in businesses; a perspective from the Western Cape. The journal of Applied Business Research, 25(4), 37-46.

Brounen, D., De Jong, A., \& Koedijk, K. (2004). Corporate finance in Europe: confronting theory with practice. Financial Management, 33(4), 71-101. https://doi.org/10.2139/ssrn.559415

Danielson, M.G., \& Scott, J.A. (2006). The capital budgeting decisions of small business. Journal of Applied Finance (Fall/Winter), 45-56.

Daunfeldt, S. \& Hartwig, F. (2012). What determines the use of capital budgeting methods? Evidence from Swedish listed companies, HUI working paper 57, Sweden, the Swedish Retail Institute (HUI).

Fernando M.S.J.S.K.D (2005). Capital investment practices in Sri Lanka: an empirical study. In International conference on business management, University of Sri Jayewardenepura Nugegoda, Sri Lanka.

Graham, J.R., \& Harvey, C.R. (2001). The theory and practice of corporate finance: Evidence from the field. Journal of Financial Economics, 60(2-3), 187-243. 
https://doi.org/10.1016/S0304-405X(01)00044-7

Hair, J.F. (2006). Multivariate Data Analysis $6^{\text {th }}$ Ed, Upper Saddle River, NJ:Prentice Hall.

Hartwig, F. (2012). The use of capital budgeting and cost of capital estimation methods in Swedish Listed Companies. The Journal of Applied Business Research, 28(6), 1451-1476. https://doi.org/10.19030/jabr.v28i6.7354

Isaga, N. (2012). Entrepreneurship and Growth of SMEs in the Furniture Industry in Tanzania, PHD Thesis, VU University Amsterdam.

John, M.S. (2007). Capital budgeting practices and performance of small firms in Tanzania. MBA Dissertation, University of Dar es Salaam.

Kaijage, E.S, (1992). The investment decision making process of Tanzanian business firms, with emphasis on financial evaluation, PhD Thesis, University of Sheffield, UK.

Kipesha, E.F. (2009). Assessment of the investment analysis techniques used by SMEs and practices in Tanzania. The case of SMEs in Morogoro Municipality. MBA thesis, University of Dar es Salaam.

Leon,F.M., Isa,M., \& Kester, G.W. (2008). Capital Budgeting Practices of Listed Indonesian Companies. Asian Journal of Business and Accounting, 1(2), 175-192.

Maziku, M. (2012). Credit Rationing for Small and Medium Scale Enterprises in the Commercial loan Market: Draft Report presented at REPOA's 17 ${ }^{\text {th }}$ Annual Research Workshop at Dar es Salaam, Tanzania on 28-29 $9^{\text {th }}$ March, 2012

Mukherjee, T.K., Henderson, G.V. (1987). The capital budgeting process: Theory and practice. Interfaces, 17(2), 78-90. https://doi.org/10.1287/inte.17.2.78

Mvula, M.H. (1988). Capital budgeting under inflation: the case of Tanzania. MBA thesis, Katholieke University.

Olawale,F., Okubena O, O., \& George, H. (2010). An investigation into the impact of investment appraisal techniques on the profitability of small manufacturing firms in the Nelson Mandela Bay Metropolitan Area, South Africa; African Journal of Business Management, 4(7), 1274-1280.

Omar, M.S. (2008). Financial constraints and structural characteristics of small and medium sized Enterprises (SMEs): The Case of Tanzania, Master Thesis, School of Economics and Management, Lund University.

Pal, K., \& Verma, M. (2011). Capital budgeting practices in manufacturing sector in India: A survey analysis. International Journal of Research in Commerce and Management, 2(2), 85-95.

Pandey I.M (1976). Essentials of financial management, $10^{\text {th }}$ ed. New-Delhi: Vikas Publishing House PVT. 


\section{Macrothink}

Journal of Management Research

ISSN 1941-899X

2018, Vol. 10, No. 4

Pratheepkanth, P., Hettihewa, S., \& Wright, C. S. (2014). Capital budgeting practices in developed and emerging countries: divergent or convergent? Proceedings of $29^{\text {th }}$ International Business Research Conference 24 - 25 November, 2014, Novotel Hotel Sydney Central, Sydney, Australia.

Runyon, L.R. (1983). Capital Expenditure Decision making in small firms. Journal of BusinessResearch, 11(3), 389-397. https://doi.org/10.1016/0148-2963(83)90020-6

Srivastava, R., \& Misra, A. (2008). Financial management, New Delhi: Oxford University Press.

Steiner G.A., Miner, J.B., \& Gray, E.R. (1986). Management Policy and Strategy, $3^{\text {rd }}$ ed. New York :Macmillan publishing Company.

Swarnapali RMNC (2015). Impact of Firm Characteristics on Capital Budgeting Techniques in Sri Lankan Listed Manufacturing Companies. International Research Symposium Rajarata University of Sri Lanka.pp 271-284

Truong, G., Partington, G., \& Peat, M. (2008). Cost of capital estimation and capital budgeting practices in Australia. Australian Journal of Management, 33(1), 95-122. https://doi.org/10.1177/031289620803300106

Uddin, M., \& Chowdhury, R. (2009). Do We Need To Think More About Small Business Capital Budgeting? International Journal of Business Management, 4(1), 112-116.https://doi.org/10.5539/ijbm.v4n1p112

UNIDO (2013). Tanzania SME Development Policy 2003 “ten years after” Implementation Review.

URT (2003).Small and Medium Enterprise Development Policy, Ministry of Industry and Trade.

Vos, A., \& Vos, E. (2000). Investment Decision Criteria In Small New Zealand. Businesses Small Enterprise Research, 8(1).44-55. https://doi.org/10.5172/ser.8.1.44

Yasmin, S. (2015). Capital budgeting in practice: an explorative study in Bangladesh companies. International Journal of Engineering, Business and Enterprise Applications, 11(2), $158-163$.

\section{Copyright Disclaimer}

Copyright for this article is retained by the author(s), with first publication rights granted to the journal.

This is an open-access article distributed under the terms and conditions of the Creative Commons Attribution license (http://creativecommons.org/licenses/by/3.0/). 